\title{
Assessment of Expert Opinion: Seasonal Sheep Preference and Plant Response to Grazing
}

\author{
Meg L. Pollock, ${ }^{1}$ Colin J. Legg, ${ }^{2}$ John P. Holland, ${ }^{3}$ and \\ Chris M. Theobald ${ }^{4}$ \\ Authors are ${ }^{1}$ Plant Ecologist and ${ }^{3}$ Upland Ecologist, Hill and Mountain Research Centre, SAC, Kirkton, Crianlarich, FK20 8RU, \\ Scotland, United Kingdom; ${ }^{2}$ Senior Lecturer, School of Geosciences, The University of Edinburgh, Crew Building, \\ The King's Buildings, West Mains Road, Edinburgh, EH9 3JN, Scotland, United Kingdom; ${ }^{4}$ Research Lecturer, \\ School of Mathematics, The University of Edinburgh, and Biomathematics and Statistics Scotland, \\ JCMB, King's Buildings, Edinburgh, EH9 3JZ, Scotland, United Kingdom.
}

\begin{abstract}
Expert opinion was sought on 2 issues relating to herbivory: seasonal sheep preferences for plant species and seasonal plant response to grazing. Expert opinion is commonly used to parameterize models: it is therefore important to assess its quality. Understanding the limitations of expert knowledge can allow prioritization of future research. Nine experts in plant or grazing ecology from Scotland/Northern England were individually interviewed. The experts ranked sheep preferences for species in 4 rangeland vegetation types and provided categorical information on plant response to grazing. For both issues, seasonal information was collected. Uncertainty (unanswered questions) on plant responses was much higher than uncertainty on sheep preferences. Uncertainty on sheep preference was significantly negatively correlated with plant species commonness, but not with quantity of scientific literature. Uncertainty on plant responses was significantly negatively correlated with both plant commonness and literature. There was agreement among experts on sheep preferences; standardized seasonal information for selected plant species is presented. In general, experts considered graminoids to be preferred over dwarf shrubs, with forbs and other species groups intermediate. Seasonal variation in sheep preference was greater for heath and mire than for grasslands. There was limited agreement among experts on seasonal plant responses. Some experts considered grazing in summer to affect growth more than grazing in winter, whereas others thought season had little effect. Sufficient agreement was found at the species level to present results on plant responses. Experts considered graminoids more resilient to grazing than dwarf shrubs. Experts agreed on sheep preference at different times of year, and on the overall resilience of plant species to grazing. However, the experts held 2 paradigms on the impact of seasonal grazing. Further research is required to explore this, because seasonal grazing regimes are currently promoted as conservation management tools.
\end{abstract}

\section{Resumen}

Se buscó la opinión experta para dos aspectos relacionados con la herbivoría: las preferencias estaciónales de los ovinos por las especies vegetales y la respuesta estacional de las plantas al apacentamiento. La opinión de expertos es comúnmente usada para parametrizar modelos: por lo tanto, es importante evaluar su calidad. Entender las limitaciones del conocimiento experto pude permitir el jerarquizar la investigación futura. Nueve expertos en ecología vegetal o ecología de apacentamiento de Escocia/ Norte de Inglaterra fueron entrevistados individualmente. Los expertos clasificaron las preferencias de los ovinos en cuatro tipos de vegetación y suministraron información categórica sobre la respuesta de las plantas al apacentamiento. Para ambos tópicos se colectó información estacional. La incertidumbre (preguntas si contestar) sobre la respuesta de las plantas fue mucho mayor que la incertidumbre respecto a las preferencias de los ovinos. La incertidumbre sobre las preferencias de los ovinos estuvo significativa y negativamente correlacionadas con lo común de las especies vegetales, pero no con la cantidad de literatura científica. La incertidumbre de las respuestas de las plantas estuvo significativamente correlacionada en forma negativa con lo común de las especies y la literatura. Hubo acuerdo entre los expertos sobre las preferencias de los ovinos; se presentó información estacional estandarizada de las especies de plantas seleccionadas. En general, los expertos consideran que las gramíneas son preferidas sobre los arbustos de porte bajo, las hierbas, y otros grupos de especies se sitúan en grupos intermedios. Evaluación de la opinión experta: la variación estacional de las preferencias de los ovinos y las respuestas de las plantas en relación a la variación estacional de la preferencia de los ovinos fue mayor para los brézales lodosos que para los pastizales. Hubo un acuerdo limitado entre los expertos sobre las respuestas estaciónales de las plantas. Algunos expertos consideraron que el apacentamiento en verano afecta más el crecimiento que el apacentamiento en invierno, mientras que otros opinaron que la época de uso tuvo poco efecto. Se encontró suficiente concordancia a nivel de especies con los resultados presentes respecto a las respuestas de las plantas. Los expertos consideran a las gramíneas mas resilentes al apacentamiento que los arbustos de porte bajo. Los expertos concordaron en las preferencias de los ovinos en las diferentes épocas del año y en la resilencia general de las especies vegetales al apacentamiento. Sin embargo, los expertos mantuvieron dos paradigmas sobre el impacto estacional del

This research was partly funded by Scottish Natural Heritage. SAC receives financial support from the Scottish Executive Environment and Rural Affairs Dept. Correspondence: Meg Pollock, SAC Kirkton, Crianlarich, FK20 8RU, Scotland, United Kingdom. Email: meg.pollock@sac.ac.uk

Manuscript received 6 March 2006; manuscript accepted 10 December 2006. 
apacentamiento. Se requiere más investigación que explore esto, ya que actualmente los regimenes de apacentamiento estacional se promueven como herramientas de manejo para la conservación.

Key Words: conflict, grassland, heathland, herbivory, knowledge, uncertainty

\section{INTRODUCTION}

Rangeland livestock farming, grazing, and vegetation management are inextricably linked. We need to understand the links for a variety of reasons-to generate policy, to enable effective farming, and to manage for conservation. However, vegetation is highly variable, being composed of many species, all of which interact individually and collectively with the environment (Grant and Hodgson 1986). Most empirical data and models still rely on expert opinion to set them into context and to extrapolate to other scenarios. How good is expert opinion on sheep preference and plant response to grazing? Does expert opinion reflect the amount of literature published in these fields? Do experts feel more confident about some species, or some times of the year, than others? Does species commonness influence the level of agreement, or does the number of scientific papers published on a species have more impact?

In future, European upland farming subsidies will be paid for maintaining the environment, especially vegetation, in a particular condition or set of conditions (Scottish Executive 2004). Some research has examined the impacts of different seasonal livestock management scenarios on upland vegetation (Grant et al. 1978; Welch 1998; Gallet and Roze 2001; Pakeman et al. 2003), but there are still gaps in the literature. In particular, grazing at different seasons as a useful tool in livestock husbandry, vegetation management, and conservation, has not been explored in detail in the United Kingdom.

This study gathered expert opinion on the seasonal preferences of sheep grazing on rangeland and the responses of rangeland plant species to seasonal grazing. These 2 variables are an important determinant of the impact of herbivory on vegetation (Augustine and McNaughton 1998), and understanding the interaction between them helps to inform rangeland management (Milne et al. 1998). Some literature on these topics is available (Hunter 1962; Gordon 1989; Clarke et al. 1995; Armstrong et al. 1997), but considerably more information and understanding could be stored in the minds of experts. Expert opinion can be collected quickly and cheaply, facilitating the use of information that might otherwise remain hidden. Areas of disagreement or uncertainty can be identified, allowing future research to be prioritized.

Scottish rangeland is dominated by the vegetation types acid grassland, heath, and mire, with small but important areas of calcareous grassland (McGowan et al. 2002). There is debate about the most appropriate balance of grassland and heathland (Bullock 1995; Morgan-Davies et al. 2003). Extensive farming and management for deer stalking (hunting) tend to increase the area of grassland, whereas management for red grouse (Lagopus lagopus scoticus) shooting maintains heathland. Acid grasslands tend to have been neglected by conservation bodies as they are seen as "degraded heathland" despite their association with important bird communities (Holland 2001). Both habitats are valuable, with some wild bird and invertebrate assemblages relying on moorland habitat (Cole et al. 2002), some (e.g., meadow pipit, Anthus pratensis; common skylark,
Alauda arvensis; and Eurasian curlew, Numenius arquata) relying on grasslands, and other species relying on a mosaic of the 2 (Buchannan et al. 2003). The choice of ideal habitat mixture for a site is a value judgment. Alongside the aim of habitat management, the objective for a majority of sites will be to continue to produce livestock. It is often difficult to meet multiple objectives simultaneously, and range managers worldwide face similar problems. The need to reconcile sustained economic livestock production with conservation of ranges has never been greater (Ormerod et al. 2003).

In this study, expert opinion was sought on sheep preferences for Scottish rangeland vegetation types and plant responses to grazing. Levels of uncertainty (quantified by the proportion of unanswered questions) and of disagreement (quantified by the variation between answers provided) were analyzed, and average opinions generated where appropriate.

\section{METHODS}

\section{Interviews}

Twelve individuals with considerable field experience of grazing or plant ecology in Scotland/Northern England, either working in ecology or recently retired, were invited to participate in the study. Nine experts were willing; they comprised 4 researchers, 2 university lecturers, 1 ecological consultant, 1 policy advisor and 1 conservation manager. The experts had a range of knowledge and experience. Four of them (experts 2, 4, 5, and 8) had extensive field experience and had published less than 6 relevant scientific papers. A further 4 (experts 1, 3, 7, and 9), had moderate field experience and had published 6 or more relevant scientific papers. One expert (expert 6) had moderate field experience and had published less than 6 papers. The interviews were conducted individually and the interviewer strove not to influence the experts' opinions. The experts were asked to use their previous field observations, experience, scientific knowledge, and reasoning to answer the questions; they were not given access to literature during interviews. The experts were encouraged to answer as many questions as possible. One expert did not answer questions about sheep preferences, and a second expert did not answer on plant responses, or on sheep preferences for the grasslands. Plant nomenclature follows Clapham et al. (1987) and Smith (1978).

Seasonal Sheep Preferences. The experts were presented with lists of plant species belonging to 4 Scottish rangeland vegetation types (Table 1). Thirty-three species, 29 vascular species and 4 bryophyte species, were listed across the 4 vegetation types. The species were chosen as representative of the vegetation types acid grassland, calcareous grassland, heath, and mire, with reference to the National Vegetation Classification (Rodwell 1991, 1992). The experts were asked to consider sheep preferences for the species, and to rank the species according to feeding preference during 6, 2-month periods through the year (January/February, March/April, 
Table 1. Expert opinion on seasonal sheep preference for plant species in 4 vegetation types, plus the levels of disagreement and uncertainty about each species. The species are arranged within vegetation types by preference, with the annually most-preferred species first. Disagreement was measured as the standard deviation (SD) of the mean over experts, averaged over the seasons. Species with the lowest SD have the least disagreement. Uncertainty was measured as the No. of experts leaving questions unanswered in any season. See Table 2 for species authorities.

\begin{tabular}{|c|c|c|c|c|c|c|c|c|c|}
\hline \multirow[b]{2}{*}{ Vegetation type } & \multirow[b]{2}{*}{ Species } & \multicolumn{6}{|c|}{ Mean standardized preference rank } & \multirow[b]{2}{*}{ Disagreement } & \multirow[b]{2}{*}{ Uncertainty } \\
\hline & & Jan/Feb & Mar/Apr & May/Jun & Jul/Aug & Sep/Oct & Nov/Dec & & \\
\hline \multirow[t]{12}{*}{ Acid grassland } & Agrostis capillaris & 1.44 & 1.36 & 1.17 & 1.35 & 1.35 & 1.37 & 0.24 & 0 \\
\hline & Festuca ovina & 0.95 & 1.04 & 0.93 & 1.05 & 0.91 & 0.85 & 0.42 & 1 \\
\hline & Deschampsia flexuosa & 0.41 & 0.73 & 0.72 & 0.64 & 0.63 & 0.50 & 0.47 & 1 \\
\hline & Danthonia decumbens & 0.53 & 0.63 & 0.69 & 0.63 & 0.67 & 0.44 & 0.90 & 3 \\
\hline & Luzula campestris & 0.12 & -0.07 & 0.24 & 0.06 & 0.22 & 0.05 & 0.70 & 1 \\
\hline & Potentilla erecta & -0.25 & -0.53 & 0.31 & 0.26 & 0.08 & -0.22 & 1.05 & 0 \\
\hline & Carex demissa & -0.17 & -0.11 & -0.28 & -0.27 & 0.05 & -0.05 & 0.66 & 1 \\
\hline & Galium saxatile & -0.40 & -0.45 & 0.14 & 0.07 & -0.25 & -0.17 & 0.79 & 0 \\
\hline & Carex binervis & -0.24 & -0.14 & -0.47 & -0.29 & -0.19 & -0.23 & 0.78 & 0 \\
\hline & Nardus stricta & -0.52 & -0.19 & -0.83 & -0.84 & -0.86 & -0.59 & 0.50 & 0 \\
\hline & Juncus effusus & -0.49 & -0.63 & -0.82 & -0.90 & -0.82 & -0.54 & 0.63 & 0 \\
\hline & Rhytidiadelphus squarrosus & -1.09 & -1.21 & -1.51 & -1.50 & -1.42 & -1.18 & 0.41 & 0 \\
\hline \multirow[t]{15}{*}{ Calcareous grassland } & Agrostis capillaris & 1.38 & 1.30 & 1.15 & 1.15 & 1.03 & 1.24 & 0.50 & 0 \\
\hline & Festuca ovina & 1.18 & 1.12 & 1.00 & 0.95 & 1.10 & 1.10 & 0.26 & 1 \\
\hline & Festuca rubra & 0.93 & 1.20 & 1.07 & 1.06 & 1.11 & 0.84 & 0.42 & 0 \\
\hline & Anthoxanthum odoratum & -0.33 & 0.65 & 0.74 & 0.64 & 0.39 & 0.15 & 0.64 & 0 \\
\hline & Vaccinium myrtillus & 0.55 & 0.37 & -0.01 & -0.13 & 0.10 & 0.24 & 0.90 & 1 \\
\hline & Carex pilulifera & 0.36 & 0.16 & -0.23 & -0.15 & -0.18 & 0.26 & 0.65 & 1 \\
\hline & Carex panicea & 0.37 & 0.09 & -0.38 & -0.31 & -0.29 & 0.25 & 0.59 & 0 \\
\hline & Campanula rotundifolia & -0.74 & -0.47 & 0.47 & 0.52 & 0.44 & -0.62 & 1.00 & 1 \\
\hline & Potentilla erecta & -0.55 & -0.58 & -0.04 & 0.29 & 0.17 & -0.31 & 0.80 & 0 \\
\hline & Achillea millefolium & -0.60 & -0.43 & 0.18 & 0.17 & 0.14 & -0.55 & 0.50 & 2 \\
\hline & Galium saxatile & -0.59 & -0.47 & -0.20 & -0.05 & 0.03 & -0.18 & 0.74 & 0 \\
\hline & Thymus praecox & -0.45 & -0.67 & -0.53 & -0.77 & -0.54 & -0.33 & 0.57 & 1 \\
\hline & Nardus stricta & 0.00 & -0.05 & -0.98 & -1.08 & -1.13 & -0.48 & 0.60 & 0 \\
\hline & Alchemilla alpina & -1.14 & -1.27 & -0.87 & -0.89 & -0.95 & -1.02 & 0.41 & 2 \\
\hline & Hylocomium splendens & -0.50 & -1.03 & -1.53 & -1.55 & -1.55 & -0.87 & 0.44 & 0 \\
\hline \multirow[t]{10}{*}{ Heath } & Agrostis capillaris & 0.93 & 0.83 & 1.46 & 1.47 & 1.31 & 1.10 & 0.59 & 0 \\
\hline & Deschampsia flexuosa & 0.29 & 0.26 & 0.89 & 1.04 & 0.57 & 0.54 & 0.70 & 1 \\
\hline & Calluna vulgaris & 1.05 & 0.92 & -0.19 & -0.02 & 0.41 & 0.86 & 0.56 & 0 \\
\hline & Vaccinium myrtillus & 0.14 & 0.27 & 0.74 & 0.56 & 0.80 & 0.46 & 0.73 & 0 \\
\hline & Erica cinerea & 0.59 & 0.46 & -0.16 & -0.22 & 0.11 & 0.15 & 0.52 & 0 \\
\hline & Carex pilulifera & -0.11 & -0.28 & 0.23 & 0.29 & 0.20 & 0.09 & 0.73 & 2 \\
\hline & Trichophorum cespitosum & -0.72 & -0.54 & 0.07 & 0.06 & -0.58 & -0.68 & 0.93 & 0 \\
\hline & Juncus squarrosus & -0.31 & -0.26 & -0.69 & -0.75 & -0.60 & -0.71 & 0.51 & 1 \\
\hline & Nardus stricta & -0.74 & -0.56 & -0.69 & -0.80 & -0.77 & -0.70 & 0.40 & 0 \\
\hline & Dicranum scoparium & -1.13 & -1.12 & -1.49 & -1.43 & -1.35 & -1.11 & 0.45 & 0 \\
\hline \multirow[t]{9}{*}{ Mire } & Calluna vulgaris & 1.44 & 1.19 & 0.20 & 0.32 & 0.86 & 1.39 & 0.46 & 0 \\
\hline & Molinia caerulea & -0.73 & 0.15 & 1.26 & 1.23 & 0.63 & -0.55 & 0.67 & 0 \\
\hline & Erica tetralix & 1.01 & 0.73 & -0.56 & -0.35 & 0.00 & 0.86 & 0.67 & 0 \\
\hline & Potentilla erecta & -0.17 & -0.40 & 0.55 & 0.46 & 0.63 & -0.03 & 0.91 & 1 \\
\hline & Eriophorum vaginatum & 0.22 & 0.19 & 0.07 & -0.24 & -0.12 & 0.13 & 0.66 & 1 \\
\hline & Trichophorum cespitosum & -0.32 & -0.28 & 0.35 & 0.06 & -0.28 & -0.19 & 0.85 & 0 \\
\hline & Eriophorum angustifolium & -0.27 & -0.27 & -0.26 & -0.10 & -0.24 & -0.17 & 0.67 & 0 \\
\hline & Narthecium ossifragum & -0.90 & -0.76 & -0.07 & 0.17 & 0.04 & -0.93 & 0.66 & 2 \\
\hline & Sphagnum spp & -0.36 & -0.62 & -1.46 & -1.49 & -1.44 & -0.61 & 0.48 & 0 \\
\hline
\end{tabular}


Table 2. Expert opinion on plant response to grazing, and uncertainty on plant response to grazing. The response to grazing values were predicted using an ANOVA model, and are averaged over experts. High values for plant response indicate the plant regrows well following grazing. See Table 3 for the original categorical scale. Estimated standard error of means $=0.057$. Key to abbreviations of phenology: $E=$ Evergreen, $S p-A=L e a f$ canopy green Spring to Autumn, Sp-Su = Leaf canopy green Spring to Summer (Grime et al. 1990). Seven plants were the subject of questions on plant response only, not sheep preferences; these are indicated in bold. Uncertainty is defined as the No. of experts leaving a question unanswered in any season.

\begin{tabular}{|c|c|c|c|c|}
\hline Group & Species & Phenology & Mean plant response to grazing & Uncertainty \\
\hline Grasses & Agrostis capillaris $\mathrm{L}$. & E & 3.3 & 0 \\
\hline Grasses & Anthoxanthum odoratum L. & E & 3.0 & 1 \\
\hline Grasses & Festuca ovina L. & E & 2.9 & 1 \\
\hline Grasses & Festuca rubra L. & E & 2.8 & 1 \\
\hline Grasses & Festuca vivipara (L.) Sm. & E & 2.7 & 1 \\
\hline Grasses & Danthonia decumbens (L.) DC. & E & 2.5 & 4 \\
\hline Forbs & Anemone nemorosa $\mathrm{L}$. & Sp-Su & 2.5 & 3 \\
\hline Grasses & Nardus stricta L. & $\mathrm{E}$ & 2.4 & 1 \\
\hline Forbs & Campanula rotundifolia L. & $\mathrm{E}$ & 2.4 & 2 \\
\hline Forbs & Alchemilla alpina L. & Sp-A & 2.3 & 5 \\
\hline Sedges & Carex nigra (L.) Reichard & $\mathrm{E}$ & 2.3 & 2 \\
\hline Forbs & Galium saxatile L. & $\mathrm{E}$ & 2.3 & 1 \\
\hline Forbs & Achillea millefolium $\mathrm{L}$. & E & 2.3 & 2 \\
\hline Forbs & Potentilla erecta (Hedw.) Warnst & $S p-A^{1}$ & 2.2 & 1 \\
\hline Sedges & Carex pilulifera $\mathrm{L}$. & $\mathrm{E}$ & 2.2 & 3 \\
\hline Grasses & Deschampsia cespitosa (L.) Beauv. & $\mathrm{E}$ & 2.2 & 2 \\
\hline Grasses & Molinia caerulea (L.) Moench. & Sp-A & 2.2 & 1 \\
\hline Rushes & Luzula campestris (L.) DC. & $\mathrm{E}$ & 2.2 & 3 \\
\hline Rushes & Juncus squarrosus L. & $\mathrm{E}$ & 2.2 & 3 \\
\hline Forbs & Narthecium ossifragum (L.) Räuschel & Sp-A & 2.1 & 2 \\
\hline Sedges & Trichophorum cespitosum (L.) Hartman & Sp-A & 2.1 & 3 \\
\hline Sedges & Carex panicea $\mathrm{L}$. & $\mathrm{E}$ & 2.1 & 2 \\
\hline Grasses & Deschampsia flexuosa (L.) Trin. & E & 2.0 & 1 \\
\hline Forbs & Thymus praecox Opiz & E & 2.0 & 2 \\
\hline Sedges & Eriophorum vaginatum $\mathrm{L}$. & E & 2.0 & 3 \\
\hline Rushes & Juncus effusus $\mathrm{L}$. & E & 2.0 & 3 \\
\hline Sedges & Carex binervis $\mathrm{Sm}$. & $\mathrm{E}$ & 2.0 & 3 \\
\hline Sedges & Eriophorum angustifolium Honckeny & E & 2.0 & 3 \\
\hline Dwarf Shrubs & Vaccinium myrtillus $\mathrm{L}$. & $S p-A^{2}$ & 1.9 & 0 \\
\hline Sedges & Carex demissa Hornem. & E & 1.8 & 4 \\
\hline Dwarf Shrubs & Arctostaphylos uva-ursi (L.) Sprengel & $\mathrm{E}$ & 1.5 & 4 \\
\hline Dwarf Shrubs & Empetrum nigrum $\mathrm{L}$. & $\mathrm{E}$ & 1.4 & 4 \\
\hline Dwarf Shrubs & Calluna vulgaris (L.) Hull & $\mathrm{E}$ & 1.4 & 0 \\
\hline Dwarf Shrubs & Vaccinium vitis-idaea $\mathrm{L}$. & $\mathrm{E}$ & 1.4 & 3 \\
\hline Dwarf Shrubs & Erica cinerea L. & $\mathrm{E}$ & 1.3 & 1 \\
\hline Dwarf Shrubs & Erica tetralix $\mathrm{L}$. & $\mathrm{E}$ & 1.2 & 2 \\
\hline
\end{tabular}

${ }^{1} P$. erecta observed by first author to have inconspicuous rosette leaves in winter.

${ }^{2} V$. myrtillus loses its leaf canopy in autumn but stems remain green all year.

May/June, July/August, September/October, and November/ December). This level of precision was selected (rather than e.g., "summer vs. winter") in order to provide information on a similar time scale to that of stock management. The most preferred species (defined as the species sheep would choose to eat first) was ranked " 1 ," the second most preferred " 2 ," and so on, up to the number of species listed for that vegetation type. Tied preferences were given joint ranks, and species considered by the experts to have no live material above ground during that 2-month period were assigned "U" for "Underground."
"N" for "Not answered," was assigned where an expert felt unable to rank a species.

Seasonal Plant Response to Grazing. The experts were then asked to provide information on the response of 36 upland plant species (Table 2) to grazing at the 6 different times of year. The species included all 29 of the vascular plants from the sheep preference lists, plus 7 other vascular species of conservation interest. Experts answered the question: If species " $\mathrm{X}$ " is grazed in a given 2-month period, how does the regrowth 
Table 3. Categories of plant response to grazing, to which experts allocated each plant species. Their task was: If species " $X$ " is grazed in a given 2-month period, how does the regrowth during April to November compare with the growth of an ungrazed individual?

\begin{tabular}{cl}
\hline Category & \multicolumn{1}{c}{ Definition } \\
\hline 0 & $\begin{array}{c}\text { Grazed plant dies (this category was not assigned by } \\
\text { any expert) } \\
\text { Regrowth considerably less than ungrazed }\end{array}$ \\
2 & Regrowth somewhat less than ungrazed \\
3 & Regrowth same as ungrazed \\
4 & Regrowth more than ungrazed \\
$\mathrm{U}$ & Underground, no live material above ground during \\
& this 2-month period \\
$\mathrm{N}$ & Not answered \\
\hline
\end{tabular}

during April to November compare with the growth of an ungrazed individual? "Grazing" was defined as resulting in the loss of two-thirds of the current year's growth. Answers were constrained to the categories in Table 3.

\section{Literature Search}

For each species, a database of scientific publications (Thompson ISI Web of Knowledge, 1981-2005) was searched for the number of papers containing its scientific name in the title, keywords, or abstract. The quality of information in the papers was not assessed.

Each vascular species' ubiquity (the number of $10-\mathrm{km}$ squares in Scotland occupied) was determined, using records of species presence above 250-m in altitude between 1987 and 1999 (Preston et al. 2002). The abundance of each vascular species (where naturally occurring) was determined using the Ecoflora database (Fitter and Peat 1994), which classifies species as 'dominant', 'frequent', or 'scattered'. These classifications were converted to the values " 3 ," " 2 ," and " 1 ," respectively. An index of commonness was created by multiplying together the ubiquity and abundance values for each vascular species. Information on bryophyte ubiquity was not available at the appropriate scale.

The experts' answers on plant response to grazing were compared to published information (Grime et al. 1990; Stace 1991; Holland 2001) about the phenology of species.

\section{Data Analysis}

Seasonal Sheep Preferences. The responses given by each expert for a combination of vegetation type and 2-month period are rankings (which can include ties) for the species, or one of the indicators: "U" that plants of a species are entirely underground in that season; or "N" that the expert was not willing to give a ranking for a species. The experts' ranks were converted to arithmetic ranks, using average values for ties and converting any "U" to the lowest arithmetic rank (as sheep only graze on plant material above ground). No rank was assigned to any "N" because they provide no information on preference. The sequences of responses vary in the numbers of times " $\mathrm{N}$ " occurs, and hence in the mean and variance of the ranks. This makes it necessary to standardize each set of ranks to have the same mean. If the total number of ranks in a set is $n$ (including those replacing " $U$ ") then the average rank assigned is $m=(n+1) / 2$. In the absence of ties, the variance of ranks from 1 to $n$ is $(n+1)(n-1) / 12$, so any rank $r$ is replaced by a standardized rank $s$ defined by:

$$
s=-\left[\frac{r-m}{\sqrt{(n+1)(n-1) / 12}}\right]
$$

Given $n$, the presence of ties reduces the variance of the ranks: this effect is ignored since it is small unless the ties occur in large groups.

Analysis of variance (ANOVA, GenStat 6.1 Committee 2002) was run on the standardized ranks for each vegetation type, including effects for expert, season, and species, and for the interactions expert $\times$ species and season $\times$ species. The usual assumptions of normality and independence do not apply to ranked data, so significance probabilities should be treated with caution. Note that with ranked data the effects of expert and season and their interaction are zero in the absence of missing values. This interaction term is omitted from the model, but Genstat includes the main effects because they are included in the remaining interactions.

The interaction between expert and species was significant for all 4 vegetation types. To explore the disagreement between experts, the standardized ranks for each combination of species and season were averaged over experts. Standard deviation (SD) of these averages was used as a measure of disagreement about each species.

Uncertainty was expressed as the proportion of unanswered questions about each species. For the 29 species occurring in both the sheep preference list and plant response list (ignoring within-expert repeats of unanswered questions across seasons and vegetation types), Spearman's rank correlation coefficients were calculated between uncertainty and both the number of papers and the index of commonness.

Plant Response to Seasonal Grazing. Before analysis, "U" answers were replaced with category 3 from Table 3, because plants that are underground are assumed to be ungrazed. Unanswered questions were treated as blanks and analyzed later for uncertainty. ANOVA on the responses showed that expert, season, and species had highly significant effects. By parsimony (i.e., choosing the model that gives the best fit using the smallest number of variables), the model fitted included effects for expert, species, season; expert $\times$ season interaction, and expert $\times$ species interaction. ANOVA means were then calculated using this model.

Strictly speaking, the plant response to grazing data are ordinal rather than interval data, although it was necessary to treat them as interval data when averaging over the factors in this study. Ordinal logistic regression (GenStat 6.1 Committee 2002) was therefore also used to examine the significance of these factors. This method is based on an assumption that the amount of regrowth varies over a continuum, and that separating this continuum into 5 disjoint intervals forms the categories 0 to 4 in Table 3. This method confirmed the importance of all the main effects and the expert $\times$ season interaction. To check whether the replacement of " $U$ " with the category 3 had caused the expert $\times$ season interaction, all species described by any 


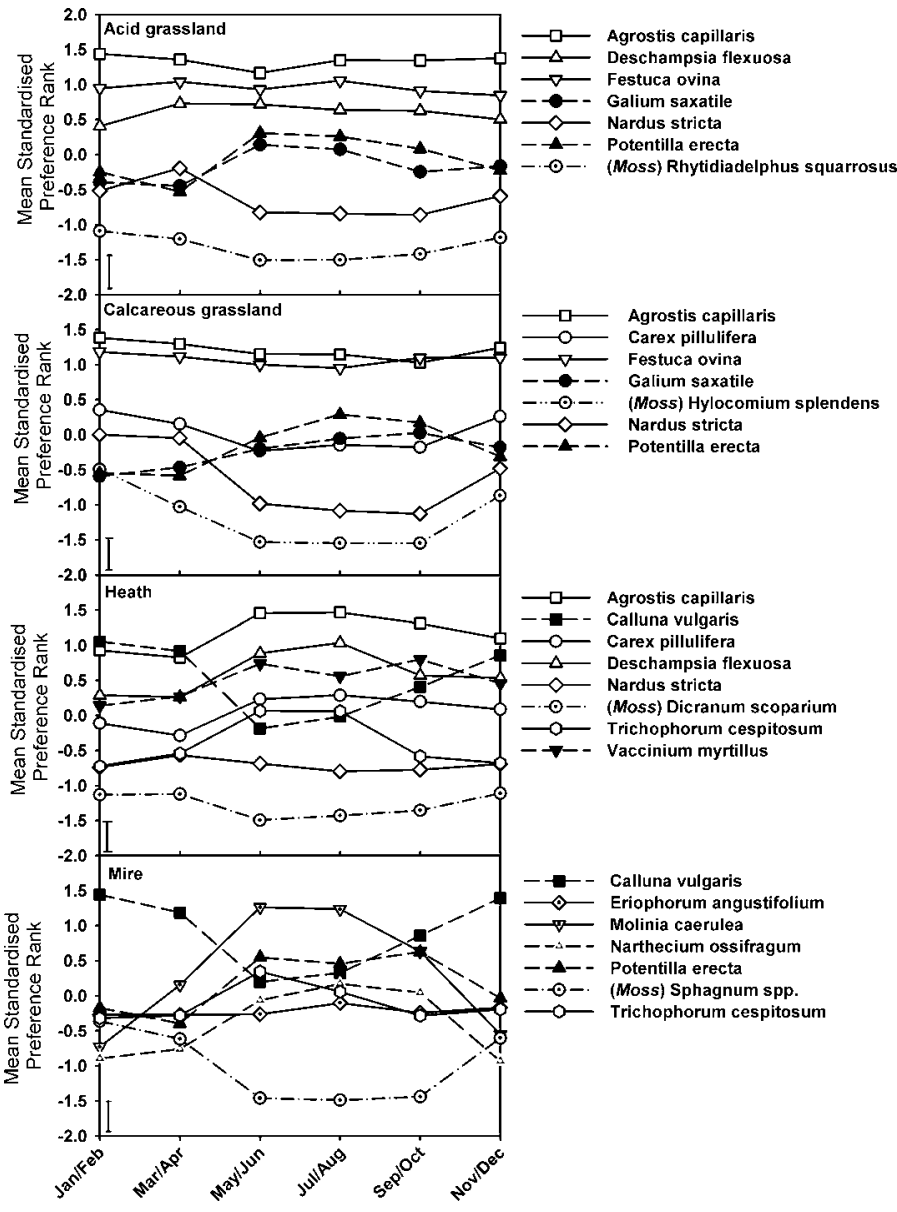

Figure 1. Fluctuation in sheep preference at different times of year within 4 rangeland vegetation types, as perceived by experts. The bar (lower left of each graph) is the maximum standard error (across experts) for the species presented in each vegetation type. Within vegetation types, the mean overall number of species is 0 for each season. Species that occurred in 2 or more of the 4 vegetation types are illustrated, plus a bryophyte species for each vegetation type and 3 common mire species.

expert as "U" were omitted from a trial ANOVA; again, the interaction was highly significant.

Uncertainty, the proportion of unanswered questions (independent of season), was calculated for each species. Spearman's rank correlation coefficients were calculated between uncertainty and both the number of papers and the index of commonness for the 29 species in both the sheep preference and plant response lists.

\section{RESULTS}

\section{Seasonal Sheep Preference}

Seasonal fluctuations in sheep preference, as perceived by experts, are considerable in heath and mire but more limited in grasslands (Fig. 1). Differences between means of plant species were highly significant $(P<0.001$, ANOVA) for all vegetation types. The interaction between plant species and season was also highly significant for all vegetation types except acid grassland, where $P=0.032$.

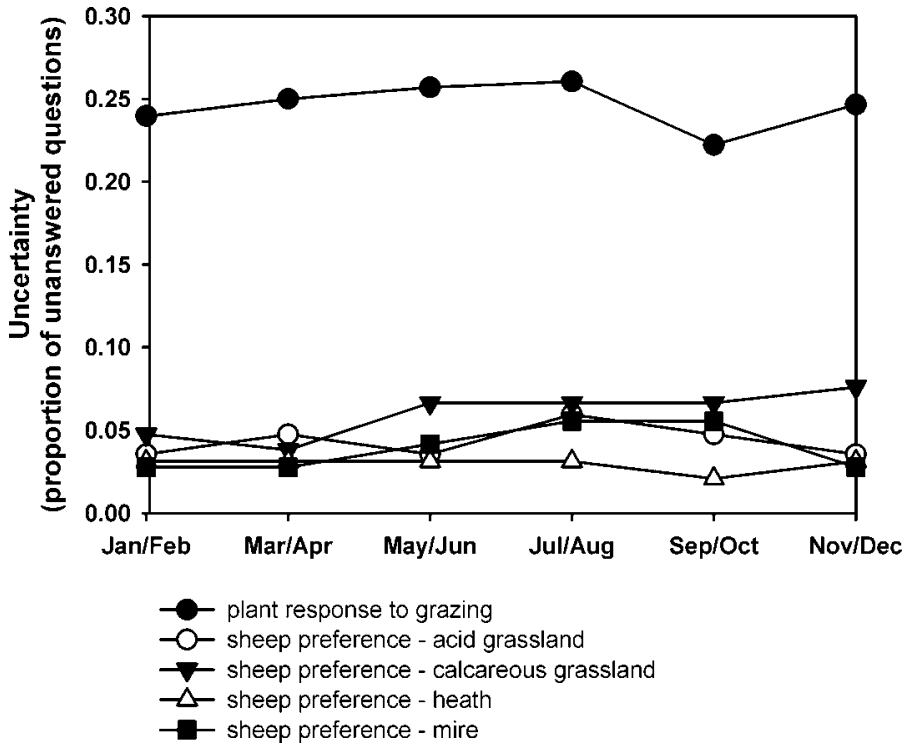

Figure 2. Uncertainty (proportion of unanswered questions) on seasonal plant response to grazing and on seasonal sheep preference for species in 4 vegetation types.

In grasslands, grass species (except Nardus stricta L.) are preferred over other species. In the heath and mire vegetation types, Calluna vulgaris (L.) Hull is perceived by experts to be the most preferred species in winter, but grasses are more preferred in summer. In general, trends in preference are consistent across vegetation types.

Uncertainty on Sheep Preference. There was little seasonal pattern in uncertainty about sheep preferences (Fig. 2). The species with the greatest number of unanswered questions was Danthonia decumbens (L.) DC., a constituent of acid grassland (Table 1), perhaps because although it is relatively common, it never becomes dominant (Grime et al. 1990).

Variation in uncertainty between experts was considerable, with 3 experts answering all 276 questions and 3 experts leaving more than 20 questions unanswered. The expert with moderate field experience and less than 6 relevant papers published had the greatest level of uncertainty. Otherwise, there was no pattern between level of uncertainty and the experts' amount of field experience or numbers of papers published. At the species level, uncertainty about sheep preference was significantly negatively correlated with plant commonness (Table 4), but not significantly correlated with number of papers published.

Disagreement on Sheep Preference. Some species had considerably lower disagreement values than others (Table 1). In acid grassland, there was better agreement about grasses (except D. decumbens) than about other functional groups. Disagreement about Agrostis capillaris L. was greater in calcareous grassland than in acid grassland. Disagreement about Potentilla erecta (L.) Räuschel was high in all 3 vegetation types in which it appeared.

Another source of disagreement between experts concerned plant species phenology (Table 5). Several experts gave sheep preference values for Molinia caerulea (L.) Moench., 
Table 4. Correlation between uncertainty (proportion of unanswered questions) and species prominence in the literature and in the field, for sheep preference and plant response to grazing. Correlations carried out using Spearman's correlation coefficients. $n=29$. ${ }^{\mathrm{NS}} P>0.05$; ${ }^{*} P<0.05 ;{ }^{*} P<0.01 ;{ }^{* *} P<0.001$.

\begin{tabular}{lcc}
\hline & Sheep preference & Plant response to grazing \\
\hline No. of scientific papers & $-0.20^{\mathrm{NS}}$ & $-0.68^{\star \star *}$ \\
Index of commonness & $-0.55^{\star \star}$ & $-0.69 * \star \star$ \\
\hline
\end{tabular}

Trichophorum cespitosum (L.) Hartman, and Narthecium ossifragum (L.) Hudson in winter (November-February inclusive), but these species have no live material above ground during winter (Grime et al. 1990).

\section{Plant Response to Seasonal Grazing}

Agreement on plant response to grazing was only sufficient to present nonseasonal information on species. According to expert opinion, grasses generally grow as well as (or in one case better than) they would have if ungrazed, whereas dwarf shrubs grow considerably less well than they would have if ungrazed (Table 2). Forbs, sedges, and rushes have an intermediate response (Table 2).

The interaction between expert and species, and between expert and season, and lack of interaction between species and season, preclude presentation of information on the behavior of individual species in different seasons.

Uncertainty on Plant Response to Seasonal Grazing. Uncertainty varied considerably between species (Table 2). There was little seasonal variation in the proportion of unanswered questions (Fig. 2). As with unanswered questions on sheep preference, variation among experts in unanswered questions on plant response was considerable, with 2 experts answering all 216 questions, 4 leaving 1 to 20 questions unanswered and 2 leaving more than 20 questions unanswered. As with sheep preferences, there was no pattern between level of uncertainty and the experts' amount of field experience or numbers of papers published. At the species level, uncertainty on plant response to grazing was significantly negatively correlated with both plant species commonness and number of papers (Table 4).

Disagreement on Plant Response to Seasonal Grazing. Problems with Phenology. The experts stated the phenology correctly for the majority of evergreen and partially evergreen species (24 of 29). There were discrepancies on phenology among experts and the literature for 4 species (Table 5). More experts' answers were at odds with the literature for sheep preferences than for plant responses (Table 5). There were also discrepancies between experts and the literature for P. erecta and Vaccinium myrtillus L. but these are explained by differences in the wording of the interviewer's question and the methods used to describe phenology in the literature.

Grazing response paradigms. There were fundamental differences between experts' views on the effect of grazing in different seasons-some (Fig. 3, top) thought grazing was less harmful in winter, while others (Fig. 3, bottom) thought season of grazing had little effect on plant response. When only evergreen plants were analyzed (i.e., those that had never been assigned " $U$ "), the pattern of greater grazing impact in summer was still observed for Experts 3, 7, and 8. Experts 1 and 9 continued to indicate no seasonal change in plant response, but Experts 2, 4, and 5 showed a pattern of greater grazing impact in winter.

\section{Overall Uncertainty}

Uncertainty was much greater for plant response to grazing than for sheep preference (Fig. 2). Sheep preference and plant response uncertainty were only slightly correlated (Spearman's $r=0.24, P=0.2, n=29)$.

\section{DISCUSSION}

\section{Expert Opinion}

In the past, ecological studies frequently used expert opinion in model building and for collating databases, but have tended to use a sole expert or to ignore any variation between individual experts (e.g., Pivello and Coutinho 1996; Pivello and Norton 1996; Campbell et al. 1999; Clevenger et al. 2002). The few exceptions included work by Iglesias and Kothmann (1998a, 1998b) who analyzed agreement between experts on herbivore preferences and plant responses to grazing and fire. However, the method used by these authors to analyze agreement on plant response to grazing gave the same weighting to minor disagreements as to major disagreements. More recent work on game management (Pellikka et al. 2005) and biodiversity (Martin et al. 2005; Scholes and Biggs 2005) has used variation between experts to improve models and estimate confidence in results.

In medical and social sciences, methods used to achieve consensus between experts include the Delphi technique (Herdman et al. 2002; Santori et al. 2004), and analytical group decision making (Schmoldt and Peterson 2000). The Delphi technique involves sending a questionnaire to experts, summarizing their answers and re-sending the questionnaire, with anonymous results, until consensus is reached. The experts are therefore expected to patiently continue answering the same

Table 5. Cases where experts and literature (Grime et al., 1990, Holland, 2001) did not agree on a species' phenology for sheep preferences and plant responses. LMAGIW = live material above ground in winter.

\begin{tabular}{lcll}
\hline \multicolumn{1}{c}{ Species } & Phenology according to literature & Sheep preferences & Plant responses \\
\hline Campanula rotundifolia & Evergreen & 6 experts said no (LMAGIW) & 3 experts said no LMAGIW $^{1}$ \\
Molinia caerulea & Winter deciduous & 3 experts said LMAGIW & 1 expert said LMAGIW \\
Trichophorum cespitosum & Winter deciduous & 4 experts said LMAGIW & 2 experts said LMAGIW \\
Narthecium ossifragum & Winter deciduous & 2 experts said LMAGIW & 3 experts said LMAGIW \\
\hline
\end{tabular}

${ }^{1}$ Winter defined as November-February, inclusive. 
questionnaire, a problem which was avoided in the current study. Analytical group decision making (Schmoldt and Peterson 2000) involves a workshop where experts meet face-to-face and follow a formal process of discussion to achieve consensus. Similar techniques have been used to attempt to predict the impacts of climate change from the opinions of a range of experts (Schneider 1985). In the current study, final sets of results were generated by averaging across experts. Morgan and Henrion (1990) warn against averaging across experts if 1 expert holds a different paradigm on the topic. In the current study, there is a risk that differences between experts might relate to actual differences in sheep behavior or plant responses between geographical areas. However, the experts appear to hold the same overall paradigm on herbivore preferences and on the impact of grazing on plant species, justifying averaging their answers. There was considerable variation between experts on the effects of season on plant response to grazing, preventing answers being averaged for this issue.

Although there were obviously differences among the experts interviewed for this study in terms of their experience in the field, their level of specialist knowledge, and ability to distinguish 2-month seasons, the authors felt that they were a good representation of the expertise in the field. Even where variation among experts is not formally analyzed, it is useful to collate expert opinion because it highlights knowledge gaps (Pivello and Norton 1996) and can stimulate collaborative research (Pivello and Coutinho 1996).

\section{Implications for management}

Uncertainty, disagreement, and conflict. Scientific uncertainty and conflict among experts can influence management options on publicly owned land and on areas with conservation designations. If experts disagree on the most appropriate management, managers are in a position to seek the opinions of those whose views support their own (Busenberg 1999). Levels of uncertainty and disagreement have implications for both strategic and tactical decisions by managers. For instance, where there is considerable uncertainty on the impact of winter grazing, a manager should have flexibility in both long-term decision-making on grazing management planning and in decisions on day-to-day livestock management.

Where there is genuine scientific uncertainty, scientists must communicate this clearly (Ascher 2004). Future European farming subsidies will be paid for environmental stewardship. If there is scientific uncertainty on how to achieve conservation objectives, management prescriptions should be avoided, and the emphasis shifted instead to writing and implementing sitespecific management plans (Morgan-Davies et al. 2005; Johnston and Soulsby 2006).

Practical management. If there is a management aim to increase the cover of a species that has relatively poor regrowth following grazing, grazing can be timed to occur during periods when that species is less likely to be selected. For instance, the experts stated that for heath and mire vegetation types, $C$. vulgaris, often a common or dominant species, is the most preferred species during winter, and graminoids are most preferred during summer. This concurs with the literature (Hobbs and Gimingham 1987; Armstrong and Milne 1995)

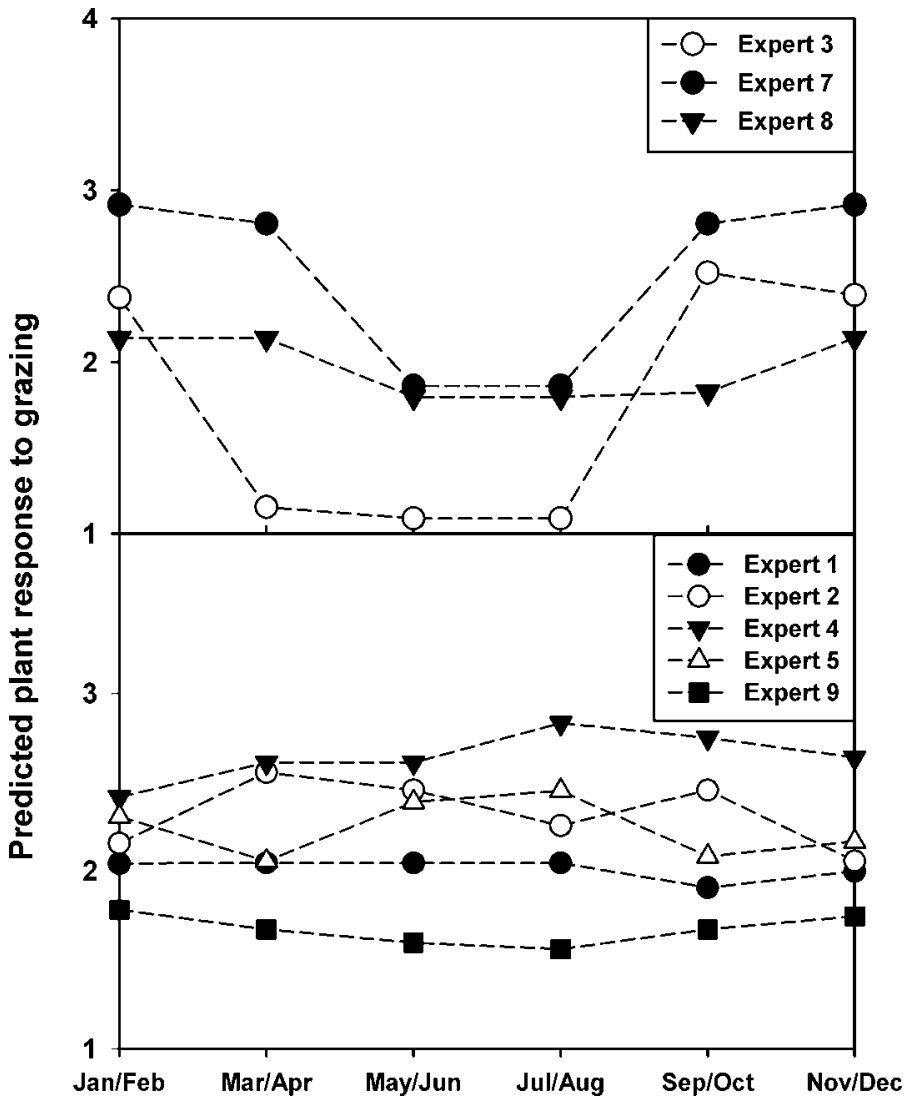

Figure 3. Contrasting paradigms of expert opinion on plant response to seasonal grazing: top, opinions of experts who think that grazing in summer has a greater impact than grazing in winter on plant response to grazing; bottom, opinions of experts who think that season has little effect on plant response to grazing. Data points are ANOVA means of individual expert opinion on impact of grazing on plants, averaged across species. Expert 6 did not answer questions about plant response to grazing.

which states that intake from heather is greater in winter when the biomass availability of species with greater nutritional quality (Agrostis and Festuca spp.) is limited. Where there is a management aim to increase cover of Calluna vulgaris, grazing in winter should be avoided. Similarly, if there is a management aim to reduce the cover of a species with poor response to grazing, stock can be put onto the site when that species is most likely to be selected. If management at a site was directed at decreasing the cover of Molinia caerulea, grazing in spring and summer would be more appropriate than at other times of the year. Herbivorous mammals are less able to be selective during winter, because food is less available at this time (Rodel et al. 2004). The experts concur with this; the moss species, which are generally least preferred, show higher preference values in winter (Fig. 1). Information on the seasonal differences in diet can facilitate management to alter species composition.

The experts stated that there was less seasonal variation in preference for the grasslands than for other vegetation types, although they expected Nardus stricta to be more preferred in spring than at other times of the year. Armstrong et al. (1986) found that voluntary intake of N. stricta was greater in June 
(early summer) than in August or December. Again, if there is an aim to reduce the amount of $N$. stricta present in a sward, spring grazing could be used.

Grasslands in Scotland are often dominated by species that are relatively palatable and that regrow quickly following grazing. The combination of many species showing good regrowth following grazing (Table 2) and a lack of seasonal pattern in preferences (Fig. 1) means it could be more difficult to effect changes in species composition in upland grasslands by using seasonal grazing regimes than in other upland vegetation types.

State and transition models of the effects of year-round grazing by sheep on Scottish upland vegetation (Miles 1988) suggest that light grazing will result in transitions from grassland to heathland and woodland, and heavy grazing in the opposite transitions. The experts' classification of species by response to grazing, with grasses generally tolerating grazing well and dwarf shrubs being checked by grazing, support this.

\section{Plant Response to Grazing}

Overall, experts concurred on the response of different species to grazing, in that they agreed on the annual average impact of grazing on plants, allowing the nonseasonal information in Table 2 to be presented. However, there appear to be 2 paradigms on the impact of seasonal grazing, with some experts considering grazing in summer to have a greater impact on plant growth than grazing in winter, whereas others think season has little effect (Fig. 3). Those who consider summer grazing to have the greatest impact could be thinking of the loss of actively photosynthesizing material, which prevents the plant from replenishing stored nutrients. For evergreen species alone, some experts considered winter grazing to have a greater impact than summer grazing. Problems for the plant relating to repairing tissues damaged during dormancy might be the reason that some experts consider winter grazing to have the greatest impact. Alternatively, the difference among experts could relate to their field of expertise; those specializing in species that store reserves in the leaves over winter (Millard et al. 2001) might expect all species to suffer from winter grazing, and vice versa.

The combined expert opinion on plant response to grazing is largely in agreement with published information. Grazed individuals of only 2 species are expected by experts to grow by the same amount or more than ungrazed individuals: Agrostis capillaris and Anthoxanthum odoratum L. (Table 2). The combined expert opinion was that when grazed, dwarf shrubs have the worst performance of all the groups of plants (Table 2).

It should be remembered that individual site circumstances (history of grazing, opportunity for seasonal rest following defoliation, soils, geology, climate, etc.) can influence plant responses, sheep preferences, and the interaction between them; caution is therefore required when applying results to specific areas (Grant and Hodgson 1986).

\section{Sources of Uncertainty}

Level of uncertainty is generally more negatively correlated with plant species commonness than with number of scientific papers. This provides evidence that field experience is important for ecological research. However, the amount of field experience that individual experts had did not appear to influence their level of uncertainty, nor did the number of papers they had published. Researchers appeared to be less likely to leave questions unanswered than those with other occupations. This could be because the experts were asked to use reasoning to answer questions where they could not use their knowledge, and researchers could be better at this than other workers. However, it is likely that personality has a large impact on level of uncertainty among experts. We have included the opinions of all experts, even those with the least experience and highest level of uncertainty, on the assumption that one can have reasonably high confidence in the stated opinions of someone who does not state them except where he/she does feel qualified to judge.

Uncertainty on Sheep preferences and Plant Responses. Uncertainty was greater for plant responses than for sheep preferences. This could be due to the speed at which the 2 variables occur; grazing is instant, whereas regrowth takes months and is therefore more difficult to observe. Also, experts were asked about sheep preferences in the context of vegetation types, whereas for plant responses, questions were asked about a list of 36 species. Any biological differences in plant response among different vegetation types will not be represented. Additionally, the task for plant responses (If species " $\mathrm{X}$ " is grazed in a given 2-month period, how does the regrowth during April to November compare with the growth of an ungrazed individual?) was more complex than that for sheep preferences (rank the species according to their feeding preference at 6 different times of the year). Another possible explanation is that experts could imagine themselves being a sheep choosing to eat different food items, but could not imagine so easily the impact of grazing on a plant. The numbers of literature hits to both topics are similar, so lack of external scientific knowledge does not explain the lower uncertainty on sheep preferences.

Further research is required on species with high uncertainty or disagreement scores, especially if they have economic/animal welfare or conservation importance. For instance, there is high uncertainty about seasonal sheep preferences for N. ossifragum a species known to cause illness in livestock (Wisloff et al. 2002). Upland calcareous grassland, a vegetation type designated under the Habitats Directive (European Community 1992), had relatively high uncertainty and disagreement. Future research should target this vegetation type, especially because changes to farming methods, imminent under European Common Agricultural Policy reform (Scottish Executive 2003), are likely to affect calcareous grasslands. For instance, the impact of simultaneously decreasing sheep numbers and increasing deer numbers requires investigation.

\section{CONCLUSIONS}

There was reasonable agreement among experts on seasonal sheep selection preferences for species in rangeland vegetation types, implying that this variable is well understood.

However, there was a lack of agreement among experts on seasonal plant response to grazing, with some experts considering grazing in summer to have a greater impact on plants than grazing in winter, whereas others considered season of grazing 
to have little effect. Given that seasonal grazing regimes are currently being used for conservation purposes (Stewart and Eno 1998; Vavra 2005), further research is required in this area. There was greater uncertainty on plant response to grazing than on sheep preference, and considerable uncertainty about some plant species, including $N$. ossifragum, a species thought to affect sheep health and productivity.

\section{ACKNOWLEDGMENTS}

The unnamed experts, who kindly provided their opinions, are thanked for their contribution. F. Bolger gave advice on dealing with unanswered questions. Three anonymous referees made helpful comments on the manuscript.

\section{LITERATURE CITED}

Armstrong, H. M., I. J. Gordon, N. J. Hutchings, A. W. Illius, J. A. Milne, and A. R SiBBALD. 1997. A model of the grazing of hill vegetation by sheep in the UK. II. The prediction of offtake by sheep. Journal of Applied Ecology 34: 186-207.

Armstrong, H. M., and J. A. Milne. 1995. The effects of grazing on vegetation species composition. In: D.B.A. Thompson, A. J. Hester, and M. B. Usher [EDS.]. Heaths and moorland; cultural landscapes. Edinburgh, United Kingdom: HMSO. p 162-173.

Armstrong, R. H., S. A. Grant, and J. Hodgson. 1986. Grazing choices and hill management. In: G. E. Pollot [ED.]. Efficient sheep production from grass: Occasional Symposium Number 21 of the British Grassland Society. Reading, United Kingdom: British Grassland Society. p 175-178.

AsCHER, W. 2004. Scientific information and uncertainty: challenges for the use of science in policymaking. Science and Engineering Ethics 10:437-455.

Augustine, D. J., AND S. J. McNaughton. 1998. Ungulate effects on the functional species composition of plant communities: herbivore selectivity and plant tolerance. Journal of Wildlife Management 62:1165-1183.

Buchannan, G. M., J. W. Pearce-Higgins, S. R. Wotton, M. C. Grant, and D. P. WhitfieLD. 2003. Correlates of the change in Ring Ouzel Turdus torquatus abundance in Scotland from 1988-91 to 1999. Bird Study 50:97-105.

BuLlock, C. 1995. Measuring the public benefits of landscape and environmental change: a case of upland grazing extensification. In: D. B. A. Thompson, A. J. Hester, and M. B. Usher [EDS.]. Heaths and moorland; cultural Indscapes. Edinburgh, United Kingdom: HMSO. p 277-281.

BusenBeRG, G. J. 1999. Collaborative and adversarial analysis in environmental policy. Policy Sciences 32:1-11.

Campbell, B. D., D. M. Stafford Smith, and M. J. Ash. 1999. A rule-based model for the functional analysis of vegetation change in Australasian grasslands. Journal of Vegetation Science 10:723-730.

Clapham, A. R., T. G. Tutin, and D. M. Moore. 1987. Flora of the British Isles. 3rd ed. Cambridge, United Kingdom: Cambridge University Press. 688 p.

Clarke, J. L., D. Welch, and I. J. Gordon. 1995. The influence of vegetation on the grazing of heather moorland by red deer and sheep II: the impact on heather. Journal of Applied Ecology 32:177-186.

Clevenger, A. P., J. Wierzchowski, B. Chruszcz, and K. Gunson. 2002. GIS-generated, expert-based models for identifying wildlife habitat linkages and planning mitigation passages. Conservation Biology 16:503-514.

Cole, L. J., D. I. McCracken, P. Dennis, I. S. Downie, A. L. Griffin, G. N. Foster, K. J. MuRPHY, AND T. WaterhouSE. 2002. Relationships between agricultural management and ecological groups of ground beetles (Coleoptera : Carabidae) on Scottish farmland. Agriculture, Ecosystems and Environment 93:323-336.

European Community. 1992. Council directive 92/43/EEC of 21 May 1992 on the conservation of natural habitats and of wild fauna and flora. $44 \mathrm{p}$.

Fitter, A. H., and H. Peat. 1994. The ecological flora database. Journal of Ecology $82: 415-425$.

Gallet, S., and F. Roze. 2001. Conservation of heathland by sheep grazing in
Brittany (France): importance of grazing period on dry and mesophilous heathlands. Ecological Engineering 17:333-344.

GenStat 6.1 Committee. 2002. GenStat. Rothamstead Experimental Station, Harperdenen, United Kingdom.

GoRdon, I. J. 1989. Vegetation community selection by ungulates on the Isle of Rhum III: determinants of vegetation community selection. Journal of Applied Ecology 26:65-79

Grant, S. A., G. T. Barthram, W. I. C. Lamb, and J. A. Milne. 1978. Effects of season and level of grazing on the utilisation of heather by sheep. I: responses of the sward. Journal of the British Grassland Society 33:289-300.

Grant, S. A., AND J. Hodgson. 1986. Grazing effects on species balance and herbage production in indigenous plant communities. In: 0. Gudmundsson [ED.]. Grazing research at northern latitudes. New York, NY: Plenum Press. p 167-178.

Grime, J. P., J. G. Hodgson, and R. Hunt. 1990. The abridged comparative plant ecology. London, United Kingdom: Chapman and Hall. 403 p.

Herdman, M., L. Rajmil, U. Ravens-Sieberer, M. Bullinger, M. Power, and J. Alonso. 2002. Expert consensus in the development of a European health-related quality of life measure for children and adolescents: a Delphi study. Acta Paediatrica 91:1385-1390.

HobBs, R. J., AND C. H. Gimingham. 1987. Vegetation, fire and herbivore interactions in heathland. Advances in Ecological Research 16:87-173.

Holland, J. P. 2001. Plant herbivore interactions within a complex mosaic of grassland, mire and montane communities [thesis]. Glasgow, United Kingdom: University of Glasgow. 409 p.

HunteR, R. F. 1962. Hill sheep and their pasture: a study of sheep grazing in southeast Scotland. Journal of Ecology 50:651-680.

Iglesias, R. M. R., And M. M. Kothmann. 1998a. Best linear unbiased prediction of herbivore preferences. Journal of Range Management 51:19-28.

IgLESIAS, R. M. R., AND M. M. Kothmann. 1998b. Evaluating expert knowledge: Plant species responses to cattle grazing and fire. Journal of Range Management 51:332-344.

Johnston, E., AND C. Soulsby. 2006. The role of science in environmental policy: an examination of the local context. Land Use Policy 23:161-169.

Martin, T. G., P. M. Kuhnert, K. Mengersen, and H. P. Possingham. 2005. The power of expert opinion in ecological models using Bayesian methods: Impact of grazing on birds. Ecological Applications 15:266-280.

McGowan, G. M., S. C. F. Palmer, D. D. French, C. J. Barr, D. C. Howard, S. M. Smart, E. C. Mackey, and E. C. Shewry. 2002. Trends in broad habitats: Scotland 1990-1998. Scottish Natural Heritage Commissioned Report F00NBO. Edinburgh, United Kingdom: Scottish Natural Heritage. 92 p.

MILES, J. 1988. Vegetation and soil change in the uplands. In: M. B. Usher and D. B. A. Thompson [EDS.]. Ecological change in the uplands. Oxford, United Kingdom: Blackwell Scientific Publications. p 57-70.

Millard, P., A. J. Hester, R. Wendler, and G. Baillie. 2001. Interspecific defoliation responses of trees depend on sites of winter nitrogen storage. Functional Ecology 15:535-543.

Milne, J. A., C. P. D. Birch, A. J. Hester, H. M. Armstrong, and A. Robertson. 1998. The impact of vertebrate herbivores on the natural heritage of the Scottish uplands-a review. Scottish Natural Heritage Review No 95. Edinburgh, United Kingdom: Scottish Natural Heritage. 127 p.

Morgan, M. G., And M. Henrion. 1990. Uncertainty: a guide to dealing with uncertainty in quantitative risk and policy analysis. New York, NY: Cambridge University Press. 344 p.

Morgan-Davies, C., A. Waterhouse, J. Holland, and C. Zografos. 2003. Assessing uptake of innovative hill land uses-retaining sheep alongside planting of new woodlands. Scottish Forestry 57:211-215.

Morgan-Davies, C., A. Waterhouse, M. L. Pollock, and K. Smyth. 2005. Local area farming plans-a common reality for farmers and conservationists in the Scottish Highlands? Scottish Geographical Journal 121:385-400.

Ormerod, S. J., E. J. P. Marshall, G. Kerby, and S. P. Rushton. 2003. Meeting the ecological challenges of agricultural change: editors' introduction. Journal of Applied Ecology 40:939-946.

Pakeman, R. J., P. D. Hulme, L. Torvell, and J. M. Fisher. 2003. Rehabilitation of degraded dry heather (Calluna vulgaris [L.] Hull) moorland by controlled sheep grazing. Biological Conservation 114:389-400. 
Pellikka, J., S. KuikKa, H. Linden, and O. Varis. 2005. The role of game management in wildlife populations: uncertainty analysis of expert knowledge. European Journal of Wildlife Research 51:48-59.

Pivello, V. R., And L. M. Coutinho. 1996. A qualitative successional model to assist in the management of Brazilian cerrados. Forest Ecology and Management 87:127-138.

Pivello, V. R., and G. A. Norton. 1996. FiRet00L: an expert system for the use of prescribed fires in Brazilian savannas. Journal of Applied Ecology 33:348-356.

Preston, C. D., D. A. Pearman, and T. D. Dines. 2002. New atlas of the British and Irish flora. Oxford, United Kingdom: Oxford University Press. 922 p.

Rodel, H. G., W. VolKL, AND H. KILIAS. 2004. Winter browsing of brown hares: evidence for diet breadth expansion. Mammalian Biology 69:410-419.

RodweLL, J. S. 1991. British plant communities. Volume 2: Mires and heaths. Cambridge, United Kingdom: Cambridge University Press. 700 p.

RodweLL, J. S. 1992. British plant communities. Volume 3: Grasslands and montane communities. Cambridge, United Kingdom: Cambridge University Press. $540 \mathrm{p}$.

Santori, G., R. Valente, F. Cambiaso, R. Ghirelli, A. G. Castiglione, and U. Valente. 2004. Preliminary results of an expert-opinion elicitation process to prioritize an informative system funded by Italian Ministry of Health for cadaveric donor management, organ allocation and transplantation activity. Transplantation Proceedings $36: 433-434$.

Schmoldt, D. L., And D. L. Peterson. 2000. Analytical group decision making in natural resources: methodology and application. Forest Science 46:62-75.

SCHNeIDER, S. H. 1985. Science by consensus: the case of the National Defense University study "Climate Change to the Year 2000": an editorial. Climatic Change 7:153-157.
Scholes, R. J., And R. Biggs. 2005. A biodiversity intactness index. Nature 434: 45-49.

ScotTISH EXECUtive. 2003. Reform of the common agricultural policy. A summary of the agreement. Edinburgh, United Kingdom: Scottish Executive. Available at: http://www.scotland.gov.uk/library5/agri/rcap-00.asp. Accessed 21 December 2005.

ScotTISH EXeCutive. 2004. The GAEC—Framework for Scotland. Edinburgh, United Kingdom: Scottish Executive. Available at: http://www.scotland.gov.uk/Topics/ Agriculture/grants/Schemes/CrossCompliance/GAECpdf. Accessed 21 December 2005.

Sмітн, A. J. E. 1978. The moss flora of Britain and Ireland. Cambridge, United Kingdom: Cambridge University Press. 706 p.

Stace, C. 1991. New flora of the British Isles. Cambridge, United Kingdom: Cambridge University Press. 1226 p.

Stewart, F. E., and S. G. Eno. 1998. Grazing management planning for Upland Natura 2000 sites. Edinburgh, United Kingdom: The National Trust for Scotland. $142 \mathrm{p}$.

Thompson ISI Web of Knowledge. 1981-2005. Available at: http://wok. mimas.ac.uk/. Accessed 4 January 2006.

VAVRA, M. 2005. Livestock grazing and wildlife: developing compatabilities. Rangeland Ecology and Management 58:128-134.

WeLCH, D. 1998. Response of billberry Vaccinium myrtillus L. stands in the Derbyshire Peak district to sheep grazing, and implications for moorland conservation. Biological Conservation 83:155-164.

Wisloff, H., A. L. Wilkins, E. Scheie, And A. Flaoyen. 2002. Accumulation of sapogenin conjugates and histological changes in the liver and kidneys of lambs suffering from alveld, a hepatogenous photosensitization disease of sheep grazing Narthecium ossifragum. Veterinary Research Communications 26:381-396. 